\title{
The Impact of a Required Undergraduate Health and Wellness Course on Students' Awareness and Knowledge of Physical Activity and Chronic Disease
}

\author{
Usha Kuruganti, University of New Brunswick
}

\begin{abstract}
As part of the undergraduate curriculum, the Faculty of Kinesiology at the University of New Brunswick (UNB) requires all students to take an undergraduate course in physical activity, health and wellness in their third year of study. This capstone course allows students to integrate concepts from their program regarding physical activity, fitness, and wellness. While students have anecdotally indicated that this course has improved their knowledge of health and wellness, this data had not been quantitatively assessed previously. The purpose of this study was to examine the effect of the course on students' views of the impact of physical activity on disease and overall health and wellness. A survey was administered to the students enrolled in the course at the beginning and again at the end of the semester. The survey requested data in four categories; 1) the demographics of the student, 2) students' knowledge of health agencies and guidelines, 3) students' physical activity, health and wellness awareness and 4) students' selfassessment of their knowledge of physical activity and chronic disease. The data showed that, at the end of the course, students felt that they improved in three areas: 1) their knowledge of health agencies and guidelines, 2) their awareness of physical activity and its impact on health and wellness and 3) their knowledge of physical activity and chronic disease. The results of this work provided information on the impact of a required health and wellness course on students' knowledge of health and suggested that the material in the course helped their overall understanding of health.
\end{abstract}

\section{Introduction}

The Faculty of Kinesiology at the University of New Brunswick (UNB) requires that all students enrolled in the bachelor's of science degree complete a required course in health and wellness in their third year. The focus of this course is on the impact of physical activity on health and wellness and, in particular, the complications that can arise due to chronic disease. The course is considered a capstone course for the faculty and students are expected to integrate concepts from their undergraduate program and apply their skills in the area of health promotion and disease prevention. In addition, the course attempts to improve the student's knowledge and awareness of health and wellness issues and the impact of his/her behavior on his/her own health as this can impact one's long term quality of life and health status. Pearman et al. (1997) reported four major influences on health status: environment, the healthcare system, human biology, and lifestyle. They continued that one aspect of promoting a healthy lifestyle has been the presence of required lifetime health and physical education classes at colleges and universities.

Much research has suggested that adult behaviours are influenced by behaviour in adolescence and young adulthood (Dishman, et al. 2013, Moore et al., 2003, Riddoch et al., 2009, Stevens et al. 2009)). In degree programs that are targeted at health sciences and/or health 
education and promotion, it is important to determine if the knowledge obtained changes or improved the attitudes that students may have regarding health education.

Surprisingly, little research has been conducted on changes in knowledge and attitudes of students who are enrolled in a community health course (Rose and Ayad, 2008). In order to investigate these changes, this study examined the effect of a required health and wellness course on students' views of the impact of physical activity on disease and their awareness of health and wellness. A survey was administered to a class of students enrolled in KIN 3282, 'Physical Activity, Health and Wellness' at the beginning of the course and again at the end of the semester. The survey requested demographic data and responses in three areas of health and wellness. The data obtained was examined for differences pre and post the course.

\section{Methods}

An attitudinal survey (Lewis and Seymour, 1997) was developed to examine students' perceptions of the course. The survey was designed to examine students' perceptions of the content of the course, the specific topics covered in the course material, and the various learning components of the course. They were provided with an overview of what the research was about and asked to be as honest as possible. Any concerns students may have had regarding their results were alleviated by having the written survey administered by a teaching assistant not connected with the research along with ensuring the principal investigator (i.e. course instructor) was absent from the classroom. The students were informed that none of the surveys would be examined until after the course instructor entered their grades at the end of the term and therefore their responses could have no impact on their final grade. The university research ethics board approved this research (REB 2013-001).

Students were asked demographic questions (e.g. age, gender, year of university study) and then asked to complete a survey and rate their understanding and knowledge of three key areas: 1) their knowledge of health agencies and guidelines (Table 1), 2) their awareness of physical activity and its impact on health and wellness (Table 2) and 3) their knowledge of physical activity and chronic disease (Table 3). For 'Knowledge of Health Agencies' students were required to answer 'yes' or 'no' to 5 questions regarding their knowledge of national surveys and public health agencies (both Canadian and international). For 'Physical Activity, Health and Wellness Awareness' and 'Self-Assessment of Knowledge of Physical Activity and Chronic Disease' students were asked to respond to a series of statements using a 5-point Likert scale (Likert, 1932) rating their responses from 'Strongly Disagree' to 'Strongly Agree'.

Table 1 Knowledge of Health Agencies and Guidelines Survey Questions

\begin{tabular}{|c|c|c|}
\hline \multicolumn{3}{|l|}{ Knowledge of Health Agencies and Guidelines } \\
\hline Please check the appropriate box for each statement below: & YES & NO \\
\hline I know about the Canadian Community Health Survey & & \\
\hline $\begin{array}{l}\text { I know about public health agencies (both Canadian and international } \\
\text { agencies) }\end{array}$ & & \\
\hline I am familiar with Canada's Food Guide & & \\
\hline $\begin{array}{l}\text { I am familiar with the Canadian Physical Activity Guidelines and the } \\
\text { Canadian Sedentary Behaviour Guidelines }\end{array}$ & & \\
\hline I seek out health information in magazines, the paper or on TV & & \\
\hline
\end{tabular}


Table 2 Physical Activity, Health and Wellness Awareness Survey Questions

\begin{tabular}{|l|l|l|l|l|l|}
\hline Physical Activity, Health and Wellness Awareness & \multicolumn{2}{|l|}{} \\
\hline $\begin{array}{l}\text { Please agree or disagree with the } \\
\text { following (check the appropriate } \\
\text { box): }\end{array}$ & $\begin{array}{l}\text { Strongly } \\
\text { Agree }\end{array}$ & Agree & Neutral & Disagree & $\begin{array}{l}\text { Strongly } \\
\text { Disagree }\end{array}$ \\
\hline $\begin{array}{l}\text { There is a relationship between } \\
\text { lifestyle factors and health }\end{array}$ & & & & \\
\hline $\begin{array}{l}\text { Taking part in physical activities can } \\
\text { make your health better and get your } \\
\text { body in better condition }\end{array}$ & & & & \\
\hline $\begin{array}{l}\text { Exercise provides an important relief } \\
\text { from the stress of everyday life }\end{array}$ & & & & \\
\hline $\begin{array}{l}\text { It is important to be required to take } \\
\text { a physical activity, health and } \\
\text { wellness course in university }\end{array}$ & & & & \\
\hline $\begin{array}{l}\text { It is important for kinesiologists to } \\
\text { understand the concepts of public } \\
\text { health and health promotion }\end{array}$ & & & & \\
\hline Studying health is important to me & & & & & \\
\hline $\begin{array}{l}\text { Health information is useful in } \\
\text { making better lifestyle choices }\end{array}$ & & & & \\
\hline $\begin{array}{l}\text { I understand how my behaviours } \\
\text { affect my health }\end{array}$ & & & & \\
\hline
\end{tabular}

Table 3 Self-Assessment of Knowledge of Physical Activity and Chronic Disease Survey Questions

\begin{tabular}{|l|l|l|l|l|l|}
\hline Self Assessment of Knowledge of Physical Activity and Chronic Disease \\
\hline $\begin{array}{l}\text { Please assess your knowledge of } \\
\text { the following (check the } \\
\text { appropriate box): }\end{array}$ & $\begin{array}{l}\text { Very } \\
\text { Good }\end{array}$ & Good & Satisfactory & Sufficient & Deficient \\
\hline $\begin{array}{l}\text { Understanding of the current } \\
\text { literature linking physical activity } \\
\text { with disease mortality }\end{array}$ & & & & \\
\hline $\begin{array}{l}\text { Understanding of the current } \\
\text { literature linking physical activity } \\
\text { with coronary heart disease }\end{array}$ & & & & & \\
\hline $\begin{array}{l}\text { Understanding of the current } \\
\text { literature linking physical activity } \\
\text { with cerebrovascular disease and } \\
\text { stroke }\end{array}$ & & & & \\
\hline $\begin{array}{l}\text { Understanding of the current } \\
\text { literature linking physical activity } \\
\text { with hypertension }\end{array}$ & & & & \\
\hline $\begin{array}{l}\text { Understanding of the current } \\
\text { literature linking physical activity }\end{array}$ & & & & \\
\hline
\end{tabular}




\begin{tabular}{|l|l|l|l|l|l|}
\hline with dyslipidemia & & & & & \\
\hline $\begin{array}{l}\text { Understanding of the current } \\
\text { literature linking physical activity } \\
\text { with obesity }\end{array}$ & & & & & \\
\hline $\begin{array}{l}\text { Understanding of the current } \\
\text { literature linking physical activity } \\
\text { with diabetes of the current }\end{array}$ & & & & & \\
\hline $\begin{array}{l}\text { Understanding of } \\
\text { literature linking physical activity } \\
\text { with osteoporosis of the current }\end{array}$ & & & & & \\
\hline $\begin{array}{l}\text { Understanding activity } \\
\text { literature linking physical } \\
\text { with cancer }\end{array}$ & & & & \\
\hline $\begin{array}{l}\text { Understanding of the current } \\
\text { literature linking physical activity } \\
\text { with mental health }\end{array}$ & & & & & \\
\hline $\begin{array}{l}\text { Knowledge of the International } \\
\text { Classification of Functioning } \\
\text { Disability and Health (ICF) }\end{array}$ & & & & \\
\hline $\begin{array}{l}\text { Understanding of physical activity } \\
\text { barriers }\end{array}$ & & & & & \\
\hline
\end{tabular}

Of the sixty-two students enrolled in the course, thirty-five completed the surveys (both pre and post course), 16 males, 19 females, mean age $=21.3$ years. A repeated measures Multivariate Analysis of Variance (MANOVA) test was run with the alpha level set to 0.05. The MANOVA allowed for comparisons between subjects and within subjects as well as any interactions. The independent variables were time of test (pre/post) and gender and the dependent variables were the responses to each survey question.

\section{Results}

There were no significant differences detected in any of the results due to gender.

\section{Knowledge of Health Agencies}

Prior to the course, $69 \%$ of students surveyed indicated that they did not know about the Canadian Community Health Survey and $46 \%$ did not know about public health agencies.

After the course there was a significant improvement in both of these areas. It was found that $86 \%$ of students knew about the survey $(\mathrm{p}<0.001)$ and an overwhelming $97 \%$ were familiar with public health agencies $(\mathrm{p}<0.001)$. No significant changes were noted for the remaining three questions. All students were aware of Canada's Food Guide. Prior to the course 25 (of 35) students indicated that they were familiar with the Canadian Physical Activity Guidelines and the Canadian Sedentary Guidelines and after the course this increased to 33. Finally, prior to the course 22 students indicated that they actively seek out health information (through television, news media, etc.) and after the course this increased to 26 students.

Physical Activity, Health and Wellness Awareness 
After completion of the course, there was a statistically significant improvement in the rating of the following question from 'neutral' to 'strongly agree' $(p=0.001)$ :

Question 4: 'It is important to be required to take a physical activity, health and wellness course in university'

Prior to the course, eight students noted that they were neutral, 15 students agreed with the questions and 12 students indicated that they strongly agreed. After completion of the course, one noted that they were neutral, nine agreed with the question and 25 indicated that they strongly agreed. No significant changes were detected in the other eight questions.

\section{Self-Assessment of Knowledge of Physical Activity and Chronic Disease}

It was found that students' responses to all twelve statements improved after the course ( $\mathrm{p}<$ 0.001). In addition, prior to the course several students responded 'deficient' in 10 of the 12 questions, however after completion of the course, no student responded 'deficient' to any of the 12 questions. Table 4 shows the full results (pre and post) for each of the 12 questions.

Table 4 Self-Assessment of Knowledge of Physical Activity and Chronic Disease Survey Questions. Note that for each question after completion of the course, no student reported 'Deficient' in any of the content modules.

\begin{tabular}{|c|c|c|c|}
\hline \multirow[t]{2}{*}{ Question } & \multirow[t]{2}{*}{ Response } & \multicolumn{2}{|c|}{$\begin{array}{l}\text { Number of Responses } \\
(\text { Total } n=35)\end{array}$} \\
\hline & & PRE & POST \\
\hline \multirow{5}{*}{$\begin{array}{l}\text { Understanding of the current literature linking } \\
\text { physical activity with disease mortality }\end{array}$} & Deficient & 1 & 0 \\
\hline & Sufficient & 3 & 0 \\
\hline & Satisfactory & 15 & 1 \\
\hline & Good & 13 & 13 \\
\hline & Very Good & 3 & 21 \\
\hline \multirow{5}{*}{$\begin{array}{l}\text { Understanding of the current literature linking } \\
\text { physical activity with coronary heart disease }\end{array}$} & Deficient & 1 & 0 \\
\hline & Sufficient & 1 & 0 \\
\hline & Satisfactory & 11 & 1 \\
\hline & Good & 19 & 13 \\
\hline & Very Good & 3 & 21 \\
\hline \multirow{5}{*}{$\begin{array}{l}\text { Understanding of the current literature linking } \\
\text { physical activity with cerebrovascular disease and } \\
\text { stroke }\end{array}$} & Deficient & 5 & 0 \\
\hline & Sufficient & 8 & 0 \\
\hline & Satisfactory & 14 & 4 \\
\hline & Good & 7 & 8 \\
\hline & Very Good & 1 & 23 \\
\hline \multirow{5}{*}{$\begin{array}{l}\text { Understanding of the current literature linking } \\
\text { physical activity with hypertension }\end{array}$} & Deficient & 2 & 0 \\
\hline & Sufficient & 5 & 0 \\
\hline & Satisfactory & 12 & 1 \\
\hline & Good & 11 & 9 \\
\hline & Very Good & 5 & 25 \\
\hline
\end{tabular}




\begin{tabular}{|c|c|c|c|}
\hline \multirow{5}{*}{$\begin{array}{l}\text { Understanding of the current literature linking } \\
\text { physical activity with dyslipidemia }\end{array}$} & Deficient & 20 & 0 \\
\hline & Sufficient & 11 & 0 \\
\hline & Satisfactory & 3 & 3 \\
\hline & Good & 0 & 15 \\
\hline & Very Good & 1 & 17 \\
\hline \multirow{5}{*}{$\begin{array}{l}\text { Understanding of the current literature linking } \\
\text { physical activity with obesity }\end{array}$} & Deficient & 0 & 0 \\
\hline & Sufficient & 1 & 0 \\
\hline & Satisfactory & 1 & 1 \\
\hline & Good & 16 & 3 \\
\hline & Very Good & 17 & 31 \\
\hline \multirow{5}{*}{$\begin{array}{l}\text { Understanding of the current literature linking } \\
\text { physical activity with diabetes }\end{array}$} & Deficient & 1 & 0 \\
\hline & Sufficient & 4 & 0 \\
\hline & Satisfactory & 8 & 1 \\
\hline & Good & 14 & 8 \\
\hline & Very Good & 8 & 26 \\
\hline \multirow{5}{*}{$\begin{array}{l}\text { Understanding of the current literature linking } \\
\text { physical activity with osteoporosis }\end{array}$} & Deficient & 1 & 0 \\
\hline & Sufficient & 7 & 0 \\
\hline & Satisfactory & 18 & 1 \\
\hline & Good & 5 & 11 \\
\hline & Very Good & 4 & 23 \\
\hline \multirow{5}{*}{$\begin{array}{l}\text { Understanding of the current literature linking } \\
\text { physical activity with cancer }\end{array}$} & Deficient & 4 & 0 \\
\hline & Sufficient & 9 & 0 \\
\hline & Satisfactory & 12 & 1 \\
\hline & Good & 8 & 10 \\
\hline & Very Good & 2 & 24 \\
\hline \multirow{5}{*}{$\begin{array}{l}\text { Understanding of the current literature linking } \\
\text { physical activity with mental health }\end{array}$} & Deficient & 2 & 0 \\
\hline & Sufficient & 7 & 0 \\
\hline & Satisfactory & 10 & 2 \\
\hline & Good & 14 & 10 \\
\hline & Very Good & 2 & 23 \\
\hline \multirow{5}{*}{$\begin{array}{l}\text { Knowledge of the International Classification of } \\
\text { Functioning Disability and Health (ICF) }\end{array}$} & Deficient & 13 & 0 \\
\hline & Sufficient & 11 & 1 \\
\hline & Satisfactory & 6 & 9 \\
\hline & Good & 5 & 10 \\
\hline & Very Good & 0 & 15 \\
\hline \multirow[b]{5}{*}{ Understanding of physical activity barriers } & Deficient & 0 & 0 \\
\hline & Sufficient & 1 & 0 \\
\hline & Satisfactory & 7 & 2 \\
\hline & Good & 20 & 6 \\
\hline & Very Good & 7 & 27 \\
\hline
\end{tabular}




\section{Discussion}

The results from this study suggested that the health and wellness course improved students' knowledge of the Canadian Community Health Survey and public health agencies. Students also indicated that the course was important to their academic program and should be required in the undergraduate program. Interestingly, students showed significant improvement in ratings in their self-assessment of knowledge of physical activity and chronic disease suggesting a positive change in their perceptions and attitudes towards healthy behaviours.

The results found here are similar to other studies of college students. Pearman et al. (1997) used a cross-sectional mail survey and compared alumni from a college that required all students to take a lifetime health and physical education course to alumni from a college that did not require this type of course. They found that the lifetime health and physical education course did have a positive effect on selected health knowledge; attitudes and behaviors compared to those were not exposed. Specifically, they found that those that took the course were more likely to know their blood pressure, blood cholesterol, and recommended dietary intake, than the comparison group. In addition, the course positively influenced students' attitudes toward exercise, eating and smoking. While their study had a much larger sample size $(n=979$ completed surveys) than the research presented here $(n=35)$, the results showed similar findings. Rose and Ayad (2008) examined the attitudes of chiropractic college students who were enrolled in a community health class to identify factors that may be associated with changes in knowledge and attitudes towards health promotion and public health concepts. They found that a course in community health improved the students' knowledge and positive attitudes towards health promotion and public health. The surveys administered by Rose and Ayad were similar to those administered in this study, as both investigations examined students' familiarity the public health system and their knowledge of public health agencies, chronic diseases and the impact of lifestyle factors on health. Similar to our data, there was little difference between genders. One topic that was not included in the present study was the knowledge of epidemiological measures and statistics. Future research should include this information as well as it provides another measure of students' abilities pre and post the course.

More recently Hastings et al. (2012) examined the impact of a one-week course on global health on the attitude of third -year medical school students. Similar to our study they used a Likert scale to examine the students' attitudes prior to and after the course. While the time frame was much shorter than the work done here (one week vs. 16 weeks), they found that there was a significant change in attitude and increase in health awareness. In our work, the survey was administered to the class during the first week of classes and administered again during the final week of classes.

One area that was not examined in this work, but that should be considered in the future is the long-term impact of these types of courses on healthy behaviours. Mack and Shaddox (2004) examined the attitudes toward physical activity and exercise of university students enrolled in Personal Wellness classes. Similar to our work, they found that students $(n=1625)$ showed a significant improvement in short-term attitude toward physical activity and exercise following completion of the university-required personal wellness course. A long study, for example surveying students in first year and again in fourth year, may provide better indications of the long term impact of health education.

In this work we focused on the student's self-assessment of changes in their knowledge and awareness regarding health and wellness. We did not determine if this actually lead to changes in behavior. DeVoe et al., (1998) surveyed 286 college students during the first and last 
week of classes in order to analyze the impact of health, fitness, and physical activity courses on their attitudes and behaviours. They found that a majority of students made a positive change in at least one significantly health-related behavior. This type of investigation would be useful in the future to determine the actual impact the course may have on behavioral change.

Finally, we did not compare grades to survey responses or change in responses to determine any correlations, however these should be examined in the future. This may provide useful information regarding academic achievement and improvement in health knowledge. It could also help to determine the efficacy of the defined course outcomes and help to determine if the objectives of the course are being met.

\section{Conclusion}

This research examined the impact of a required undergraduate course in health and wellness on students' awareness and knowledge of physical activity and chronic disease. All students were enrolled full-time in an undergraduate bachelor's of science degree in kinesiology. The results obtained suggested that the course was an important part of the students' academic program and that by the end of the term, students' knowledge of health and wellness improved. It was encouraging to also note that students showed significant improvements in their self-assessment of knowledge of physical activity and chronic disease. Two areas for future consideration are 1) the long-term implications of these types of courses and 2) the relationship between academic achievement (grades) and changes in awareness and knowledge.

\section{Author's Biography}

Usha Kuruganti is an Associate Professor in the Faculty of Kinesiology at UNB and Co-Director of the Andrew and Marjorie McCain Human Performance Laboratory within the Richard J. CURRIE Centre at UNB. Her research interests include human movement analysis and human factors engineering. Her scholarly work focuses on teaching methodologies, problem based learning and engineering accreditation.

\section{References}

DeVoe, D, Kennedy, C, Ransdell, L, Pirson, B., DeYoung, W., and Casey, K. (1998). Impact of health, fitness, and physical activity courses on the attitudes and behaviours of college students. Journal of Gender, Culture and Health, 3(4), 243- 255.

Dishman, R., Health, G. and Lee, I-M. (2013). Physical Activity Epidemiology, $2^{\text {nd }}$ Edition. Human Kinetics, Champaign, IL.

Hastings, A., Pardiñaz-Solis, R., Phillips, M. and Hennessy, M. (2012). Measuring attitude change in medical students: lessons from a short course on global health. Medical Education Development, 2, 1- 4.

Lewis, E.\& Seymour, E. (1997). Attitudinal survey. Retrieved June 1, 2013, from http://www.flaguide.org/extra/download/cat/attitude/attitude.pdf

Likert, Rensis (1932). "A technique for the measurement of attitudes". Archives of Psychology $140,1-55$. 
Mack, M \& Shaddox, L. (2004). Changes in short-term attitudes toward physical activity and exercise of university personal wellness students. College Student Journal, 38(4), 587593.

Moore, L.L., Gao, D., Bradlee, J.L., Cupples, A., and Sundarajan-Ellsion, R.C. (2003). Does early physical activity predict body fat change throughout childhood? Preventive Medicine, 37, 10-17.

Pearman, S., Valois, R., Sargent, R. Sunders, R., Drane, W., and Macera, C. (1997). The impact of a required college health and physical education course on the health status of alumni. Journal of American College Health, 46, 77 - 85.

Riddoch, C.J., Leary, S.D., Ness, A.R., Blair, S.N., Deere, K. Mattocks, C., Griffiths, A., Davey Smith, G., and Tilling, K. (2009). Prospective associations between objective measures of physical activity and fat mass in $12-14$ year old children: The Avon Longitudinal Survey of Parents and Children (ALSPAC). British Medical Journal 339: b4544.

Stevens, J., Truesdale, K.P., Wang, C.H., and Cai, J. (2009). Prevention of excess gain. International Journal of Obesity (Land) 33:1207-1210. 